\title{
Anthropogenic Source Contributions to Ozone Formation in the Greater Houston Area
}

\author{
Iqbal Hossan1, Hongbo Du1, Raghava R. Kommalapati1,2* \\ ${ }^{1}$ Center for Energy \& Environmental Sustainability, Prairie View A \& M University, Prairie View, USA \\ ${ }^{2}$ Department of Civil \& Environmental Engineering, Prairie View A \& M University, Prairie View, USA \\ Email: iqbal.hossan@adeq.state.ar.us, ^rrkommalapati@pvamu.edu,hodu@pvamu.edu
}

How to cite this paper: Hossan, I., Du, H. and Kommalapati, R.R. (2021) Anthropogenic Source Contributions to Ozone Formation in the Greater Houston Area. Journal of Environmental Protection, 12, 249-264. https://doi.org/10.4236/jep.2021.124016

Received: March 22, 2021

Accepted: April 18, 2021

Published: April 21, 2021

Copyright $\odot 2021$ by author(s) and Scientific Research Publishing Inc. This work is licensed under the Creative Commons Attribution International License (CC BY 4.0).

http://creativecommons.org/licenses/by/4.0/

\begin{abstract}
The Houston-Galveston-Brazoria (HGB) area of Texas has historically experienced severe air pollution events with high concentrations of ozone $\left(\mathrm{O}_{3}\right)$ during the summer season. This study evaluates the contribution of different anthropogenic sources to ozone formation in the HGB area. The Emission Processing System (EPS3) is used to process emission files in four different scenarios (Base case as including All emission sources (BC), All sourcesArea sources (AMA), All sources-Point sources (AMP), and All sourcesMobile sources (AMM). These files are used as input in photochemical modeling with the Comprehensive Air Quality Model with Extensions (CAMx) to simulate ozone formation. The data is analyzed for daily maximum ozone concentrations and contribution of source categories at three air quality monitoring locations (La Porte Sylvan beach-C556, Houston Texas avenue-C411, and Texas city in Galveston-C683) for a study period of June 1-June 30, 2012. The contribution of the point sources to ozone formation is dominated at all three locations, followed by mobile sources and area sources on high ozone days. The relative contributions of point sources are $27.51 \% \pm 3.53 \%, 21.45 \%$ $\pm 7.36 \%$, and $30.30 \% \pm 9.36 \%$; and mobile sources are $18.27 \% \pm 2.22 \%, 20.60 \%$ $\pm 6.89 \%$, and $18.61 \% \pm 7.43 \%$; and area sources were $4.2 \% \pm 1.65 \%, 5.21 \% \pm$ $1.59 \%$, and $3.72 \% \pm 1.52 \%$ at C556, C411, and C683, respectively. These results demonstrate the importance of regulatory focus on controlling point and mobile source emissions for NAAQS attainment in the study region.
\end{abstract}

\section{Keywords}

Anthropogenic Sources, CAMx, Model Sensitivity, Ozone Precursors

\section{Introduction}

The air pollutant ozone refers to tropospheric or ground-level ozone. Ground-level 
ozone $\left(\mathrm{O}_{3}\right)$ formation depends on the complex reaction of volatile organic compounds (VOCs) and $\mathrm{NO}_{\mathrm{x}}$ in the presence of solar radiation [1], most abundantly during hot, sunny summer days [2]. Formation of peroxy radicals $\left(\mathrm{RO}_{2}\right)$ is the major role of VOCs, which convert nitrogen monoxide (NO) back to nitrogen dioxide $\left(\mathrm{NO}_{2}\right)$ without consuming $\mathrm{O}_{3}$ and reproduce hydroxyl radical $(\mathrm{OH})$ to allow sustained net $\mathrm{O}_{3}$ formation [3] [4]. An early study explained ozone chemistry in the troposphere and the simplified photochemistry shown in chemical reactions Equations (1) to (4) where $\mathrm{OH}$ and $\mathrm{HO}_{2}$ are short-lived radicals and carbonyl compounds play role in further oxidation steps [3]. There are six criteria pollutants identified by the U.S. Environmental Protection Agency (USEPA) under the Clean Air Act (CAA) that can harm public health, environment and cause property damage. Ozone is one of these and has been found to cause respiratory system inflammation and decrease lung capacity. Higher ozone in the air is associated with the increased rates of hospital admissions, emergency room visits, and respiratory-related deaths [5].

$$
\begin{gathered}
\mathrm{VOC}+\mathrm{OH}+\mathrm{O}_{2} \rightarrow \mathrm{H}_{2} \mathrm{O}+\mathrm{RO}_{2} \\
\mathrm{RO}_{2}+\mathrm{NO}+\mathrm{O}_{2} \rightarrow \mathrm{HO}_{2}+\mathrm{NO}_{2}+\text { carbonyl compounds } \\
\mathrm{HO}_{2}+\mathrm{NO} \rightarrow \mathrm{NO}_{2}+\mathrm{OH} \\
\mathrm{NO}_{2}+\mathrm{O}_{2}+\mathrm{hv} \rightarrow \mathrm{NO}+\mathrm{O}_{3}
\end{gathered}
$$

The USEPA sets National Ambient Air Quality Standards (NAAQS) for criteria pollutants as required by the CAA to protect human health and welfare. In 1979 , the $\mathrm{O}_{3}$ NAAQS was set to $0.12 \mathrm{ppm}$ for 1-h average and not be exceeded more than one day per year for three years. The standard was revised to 0.08 ppm and $0.075 \mathrm{ppm}$ for the fourth-highest maximum daily 8-hour averaging time in 1997 and 2008, respectively. A more stringent NAAQS was mandated in 2015 , and the 8-hour standard decreased to $0.070 \mathrm{ppm}$ [6]. If an area exceeds this limit which is annual fourth highest daily maximum 8-hour average and averaged over three years, it is designated as a nonattainment area [6]. Texas has been in the nonattainment states for ozone compliance; the Houston-GalvestonBrazoria (HGB) area experienced frequent high $\mathrm{O}_{3}$ events, and the rate of $\mathrm{O}_{3}$ formation raised as high up as $200 \mathrm{ppb} \mathrm{h}^{-1}$, in contrast to maximum of $40 \mathrm{ppb} \mathrm{h}^{-1}$ in other urban areas [7]. The HGB region is in "marginal nonattainment" status for 8-hour $\mathrm{O}_{3} \mathrm{NAAQS}$, and the attainment deadline is August 3, 2021 [8].

Emissions from various sources have been recognized as the most predominant factors of ozone formation, along with meteorological parameters [9]. Ozone formation in the HGB area is caused by various emission sources, and the dominant sources are mobile sources, point sources, area sources, and biogenic sources [10]. These sources emit $\mathrm{CO}_{2}, \mathrm{CO}, \mathrm{SO}_{2}$ and ozone precursors $\mathrm{NO}_{\mathrm{x}}$ and VOCs, etc. However, the extensive petrochemical industries contribute both $\mathrm{NO}_{\mathrm{x}}$ and VOCs to the pollutant mix and make HGB a unique region [11]. For example, an early study observed that petrochemical facilities around the Houston Ship Channel (HSC) play a significant role in the occurrence of ozone exceedance [12]. According to Murphy et al. (2005), the petrochemical industrial 
emissions contributed to the rapid and efficient ozone formation, and their study showed that high concentration of light olefins especially butene, propane, ethane, and 1,3-butadiene was in the plumes occurring rapid ozone formation [13], These light olefins are designated as highly volatile organic compounds (HRVOCs) by the state of Texas. Electricity Generation Units (EGUs) are the leading point source emitters of $\mathrm{SO}_{2}$ and $\mathrm{NO}_{\mathrm{x}}$, which are associated with the formation of photochemical ozone and acid deposition [14] [15] [16]. Our previous study on biomass co-firing with coal in the W. A. Parish power plant in Houston showed that a $10 \%-15 \%$ reduction of $\mathrm{NO}_{\mathrm{x}}$ and $\mathrm{VOC}$ from the power plant could have a marginal decrease of ozone production in downwind areas [17]. In the HGB area, point, area, and mobile sources contributed $61 \%, 16 \%$, and $23 \%$ respectively in 2014 and $67 \%$ of $\mathrm{NO}_{\mathrm{x}}$ emitted from mobile sources in the same year [17]. A photochemical modeling study shows that mobile sources have a dominant effect on ozone formation at Sugarland, Bayland, and Conroe areas in the Greater Houston region [18]. In the summer season, the HGB region experiences hot and humid conditions with intense solar radiation that can be conducive for $\mathrm{O}_{3}$ formation as a high concentration of ozone mainly develops in sunny days with light wind speed, which allows more pollutants to form and accumulate [10]. Ozone concentrations in the HGB area are known to be high through favorable emissions and meteorological conditions [11] [19]. Neilson-Gammon et al. (2005) pointed out that weak local winds, high frequency of winds from the north during September, high temperatures, and abundant sunshine lead to high ozone levels [20]. In late summer, the local meteorology is usually dominated by the mesoscale land-sea breeze circulation, which causes the top ozone episodes, and also strong sunlight and high temperatures lead to rapid photochemical reactions of HRVOCs and $\mathrm{NO}_{\mathrm{x}}$ emitted from the sources along with the HSC and Galveston Bay [21] [22] [23]. The rapid ozone production near the sources was also observed by Nam et al. (2006) [24]. In late summer and early fall, the northerly and easterly flowing associated with synoptic-scale circulations transports continental ozone rich air to the eastern Texas region and causes higher background ozone [25].

Controlling ozone is a complex issue that depends on the emission and meteorological characteristics within the region. The literature review recognizes the limitation of studies on analyzing the ozone exceedances due to different sources in the HGB region. There are various studies on analyzing ozone source contributions using the Comprehensive Air Quality Model with Extensions (CAMx) or the Community Multiscale Air Quality Modeling System (CMAQ) in China. For example, Zhang et al. (2012) observed the source apportionment of PM2.5 from multiple sources [26]; Wang et al. (2009) and Li et al. (2012) studied ozone source contribution using OSAT technology in CAMx in Beijing and the Pearl River Delta region in China [27] [28]. A modeling analysis of ozone sources using different source combination cases in the Houston area showed that mobile sources are dominant for ozone production at the three different locations in the HGB region [18]. There exists a significant gap regarding the sources affecting 
the high-level ozone formation in the greater Houston area. An analysis to understand and determine the ozone sources in various parts of the HGB region would help the policymakers to keep ozone in attainment status.

The current study uses Emission Processor v3 (EPS3), CAMx photochemical modeling, and the Visualization Environment for Rich Data Interpretation (VERDI) tool to analyze ozone source contributions. The primary objective of this research is to identify sources that are mostly responsible for the high ozone episodes in the HGB area.

\section{Methodology}

The main objective of this analysis is to understand the impacts of various major source categories in the higher ozone episodes in the greater Houston area. There are different variables of ozone formation, such as source categories, emission quantity, meteorology of the interested region, and the background pollutants.

\subsection{Emission Scenarios and Processing}

This study created four emission scenarios by combining different source categories to understand better which source category affects more in higher ozone days. The scenarios are Base case as All sources (BC), All sources-Area sources (AMA), All sources-Point sources (AMP), and All sources-Mobile sources (AMM). The $\mathrm{BC}$ includes all the anthropogenic emission categories, such as area sources, mobile sources, and point sources. And the other scenarios were developed by subtracting a single major source category from all sources case and used to determine impact by each category. This method is called the zero-out method which has been used extensively in different photochemical modeling studies, and it was also adopted by USEPA [29] [30]. The zero-out runs affected by nonlinearity in chemical reactions. There are other methods such as ozone source apportionment technology (OSAT) tool which is a mass balance analysis technique to identify source contribution that can address non-linear species, and Decoupled Direct Method (DDM) method that calculates first and high order sensitivity coefficients with high computational efficiency but may not capture non-linearity effectively [29] [30] [31]. The biogenic source was always included in all cases by an assumption that it would not be controlled. All the emission files were collected from the Texas Commission of Environmental Quality (TCEQ) 2012 modeling episodes [32]. The emission inventories were prepared by using EPS3, which consists of a series of FORTRAN modules that perform intensive data manipulations [33]. A module available in the EPS3, MeRGeUAMfiles (MRGUAM), was used to merge multiple emission files into one file for the modeling purpose.

\subsection{Model Selection and Modeling Domain}

This study used CAMx 6.3 to simulate the evolution of air pollutant concentrations in the study region. The lambert conformal conic map projection was used 
to develop modeling domains, and the coarsest master grid domain was $36 \mathrm{~km}$, which covers the area under easting $(-2735,2592)$ and northing $(-2088,1944)$ coordinates. The master grid area divided into $148 \times 112$ cells and covers emission sources in the US, Canada, and Mexico, and then grids move to finer as 12 $\mathrm{km}$ and $4 \mathrm{~km}$ domain selected in the process. The finer grids have $149 \times 110$ and $191 \times 218$ cells in the $12 \mathrm{~km}$ and $4 \mathrm{~km}$ domains, respectively. The CAMx input files, such as meteorological files, initial condition, boundary condition, chemistry parameters, photolysis rates, land use, etc., were obtained from the TCEQ website [32]. The meteorology files were generated with the Weather Research and Forecasting (WRF) model by TCEQ. VERDI was used to visualize the pollutant concentrations from the $4 \mathrm{~km}$ grid CAMx results.

\subsection{Site Selection}

After photochemical reaction modeling, the simulation results were analyzed as hourly ozone concentrations and the contribution of source categories at three air quality monitoring locations. Figure 1 depicts the locations of three selected sites on a map. Houston Texas avenue-C411 is located downtown in Houston, which is in the most populated county (Harris) in the Texas. Harris county topped in total $\mathrm{NO}_{\mathrm{x}}$ and VOC emissions in all counties of HGB area and the 8-hour ozone concentration of C411 was recorded 78 ppb in 2012 which was designated in non-attainment level [34] [35]. La Porte Sylvan beach-C556 is near HSC, and a large number of petrochemical facilities and Texas city-C683 is in Galveston county near the Galveston beach. Multiple studies displayed the Houston Ship Channel emissions and petrochemical emissions from Texas City area dominates the rapid ozone formation in the greater Houston area and the larger contributors to peak $\mathrm{O}_{3}$ concentrations in the HGB area [36] [37]. The geographical coordinates of these sites are $\left(29.65527^{\circ},-95.00972^{\circ}\right),\left(29.75277^{\circ}\right.$, $\left.-95.35027^{\circ}\right)$, and $\left(29.37870^{\circ},-94.91019^{\circ}\right)$ for C556, C411, and C683 respectively.

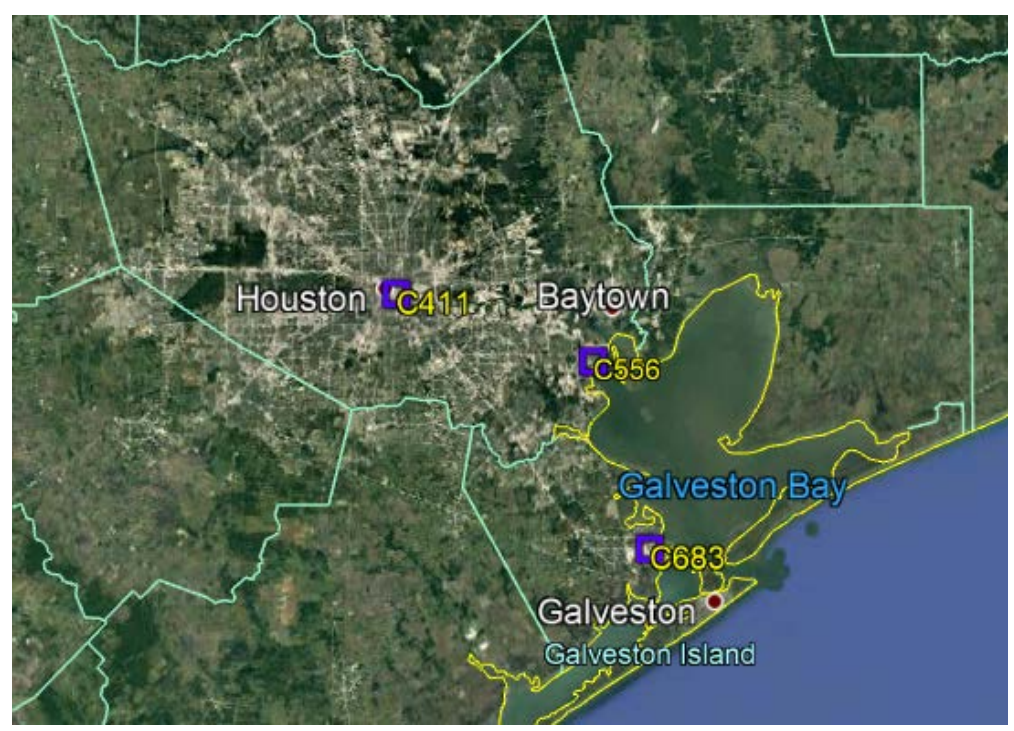

Figure 1. Selected locations in this study. 
The photochemical simulation was performed for 30 days, starting from June 1, 2012. Also, a 15-day simulation from May 16 to May 31, 2012, was performed as model spin-up, so that initial conditions of the modeling domain were washed out of before the study period.

\subsection{Model Sensitivity}

This study calculated two statistical parameters namely Fractional Bias (FB) and Coefficient of determination $\left(\mathrm{R}^{2}\right)$ for the sensitivity analysis of the modeled vs observed data. The standard range for the FB is $-200 \%$ to $+200 \%$, and 1 for the $\mathrm{R}^{2}$ [38]. The FBs for the sites C556, C683, C411 are 25.7\%, 33\%, and 10\%, respectively, and the $\mathrm{R}^{2}$ values are $0.65,0.63$, and 0.67 , respectively. The graphical representation of the modeled vs. observed data is shown in Appendix A. A study conducted by TCEQ showed that the FB and $\mathrm{R}^{2}$ are $17 \%$ and 0.66 for all the monitors in Texas during the June 2012 [38].

\section{Results and Discussion}

After the photochemical model simulation, pollutant concentrations were visualized and extracted for the three sites by using VERDI. The diurnal variations of all the scenarios are plotted for direct comparison.

The maximum $\mathrm{O}_{3}$ concentration (128 ppb) at all three locations was observed at 15:00 hr on June 26 at 6683 station in the study period for the base case (Figure 2). The peak concentrations at C411 and C556 occurred on the same day at 15:00 and 16:00 hrs at $105 \mathrm{ppb}$ and $82 \mathrm{ppb}$, respectively. Two of the major meteorological factors for the high ozone level on June 26 were low cloud cover and high temperature.

The C411 station at downtown Houston had more elevated ozone hours than other sites and lower ozone level in June 2012 is observed in the mid-10 days of the month. In most of the days at all the sites, the ozone concentration remained low from midnight to morning, and a sharp increase was observed from 10:00 $\mathrm{hr}$, kept climbing till 16:00 hr, until it reached the peak. The concentration dropped sharply with minor variation. The restricted vertical mixing and light winds allow high levels of pollutants to accumulate during night and morning hours, and the nocturnal land breeze carries the pollutants out over the Galveston

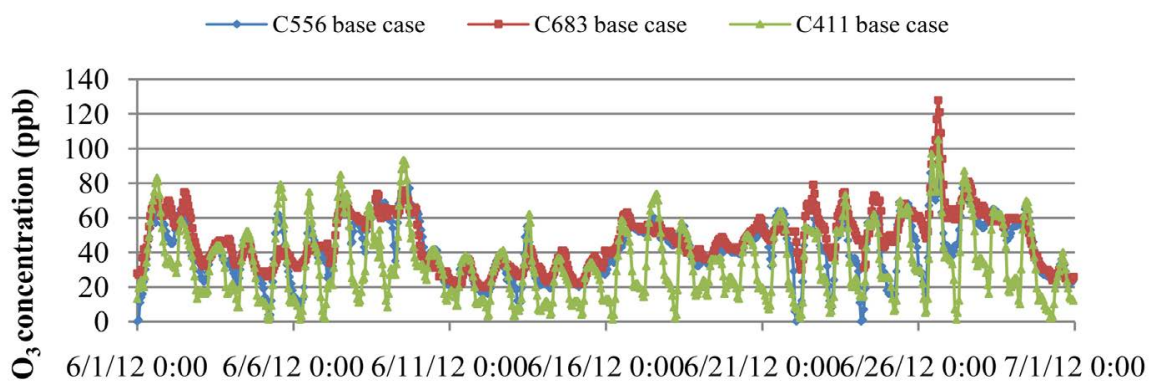

Time

Figure 2. Ozone concentrations at three locations for all sources case (base case). 
Bay and into the Gulf of Mexico. The sea breeze flow reversal carries $\mathrm{O}_{3}$ back into the city during the daytime in the high ozone days while ozone precursor emissions get diluted and taken out of the area by persistent stronger winds in low concentration days [39]. A study reported that VOC-sensitive $\mathrm{O}_{3}$ formation is more vigorous than $\mathrm{NO}_{\mathrm{x}}$ sensitive formation in the HGB area [40]. Hossan et al. (2018) reported that the C556 site showed VOCs sensitive to ozone formation in most of the hours on June 12 [17]. Most of the high ozone hours occurred on weekdays except June 9 (Saturday) at all locations and June 2 (Saturday) and June 23 (Saturday) at site C683, which can be explained as "weekend effect". The weekend effect is defined as higher $\mathrm{O}_{3}$ concentrations occur in the weekend than weekdays, and it is typically hypothesized that the emissions from mobile sources dominate during that period [39].

Time series ozone concentrations were plotted for different scenarios by removing each main anthropogenic source category from the Base case. In the AMM scenario, the maximum $\mathrm{O}_{3}$ concentration (111 ppb) for the June episode was observed at $\mathrm{C} 683$ on June 26 when mobile source emissions were removed (Figure 3). In most days, the daily peak ozone level was observed at C411. Lower concentrations were observed in the mid-10 days of the month. Most of the daily peaks during the high concentration days occurred in the afternoon with some variation, while minimum ozone levels were observed at midnight to early morning. When mobile sources are neglected, the lower daily peak concentrations were observed near the HSC area most of the days. It has been observed that the ozone formation rate in the ship channel area is much higher than the downtown Houston mainly because of much higher hydrocarbon reactivity, which mainly comprises low molecular weight alkenes [41].

In the AMP scenario, the highest concentration (90 ppb) of the episode was observed at C411 on the same day as AMM. At most of the sites, the daily maximum occurred between 10:00-16:00 hr. The higher variation of ozone concentration from minimum to maximum occurred at C411 in most of the days, which shows a sharp increase in ozone levels in the daytime (Figure 4). It is reported that the oak forest area near the Houston city emits large amounts of isoprene and reacts with $\mathrm{NO}_{\mathrm{x}}$ emitted by petrochemical industries and other anthropogenic sources in the area [39]. The daily peak concentration at C556 is

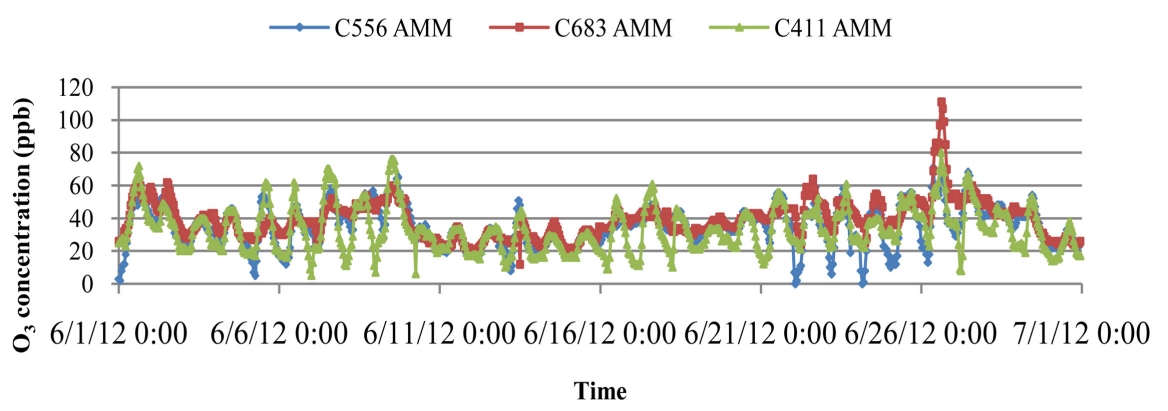

Figure 3. Hourly $\mathrm{O}_{3}$ concentrations at different locations for AMM (All sources-Mobile sources) case. 
comparatively lower than other sites when point sources are removed. The site in the HSC area is mostly affected by VOCs for ozone formation [17]. Also, point sources such as $\mathrm{NO}_{\mathrm{x}}$ emissions from EGUs play a vital role at site C556 to ozone formation. The reduction of $\mathrm{NO}_{\mathrm{x}}$ in an amount of $50 \%$ from the HGB area would result in a $15 \%$ reduction of ozone in the HSC area [42]. The phenomena could be explained as that point sources are one of the major categories of $\mathrm{NO}_{\mathrm{x}}$ emissions, and their removal would result in lower $\mathrm{O}_{3}$ concentrations in the HSC area.

When area sources were neglected, the maximum concentration of the study period was observed at 15:00 $\mathrm{hr}$ on June 26 at Galveston site C556 (Figure 5). The daily peak concentration was lower than other sites in most of the real high concentration days. The large cluster of petrochemical facilities that emits $\mathrm{NO}_{x}$ along with a variety of VOC precursors makes HSC unique from the other parts of HGB. The TCEQ (2009) observed that the distinctive photochemistry and the highest concentrations of HRVOCs originate from the Houston Ship Channel predominantly [39]. The same study reported that this unique combination in HSC leads to significant rapid $\mathrm{O}_{3}$ production as quickly as an hour, while other areas in the U.S. observed ranged from an entire day to several days. The daily peaks predominantly occurred in the Houston downtown area in the first ten

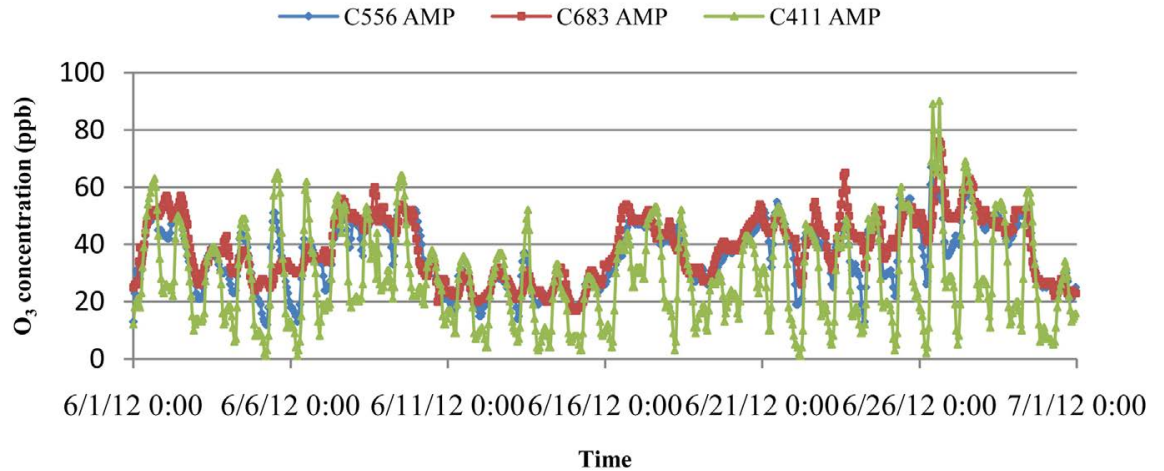

Figure 4. Hourly $\mathrm{O}_{3}$ concentrations at different locations for AMP (All sources-Point sources) case.

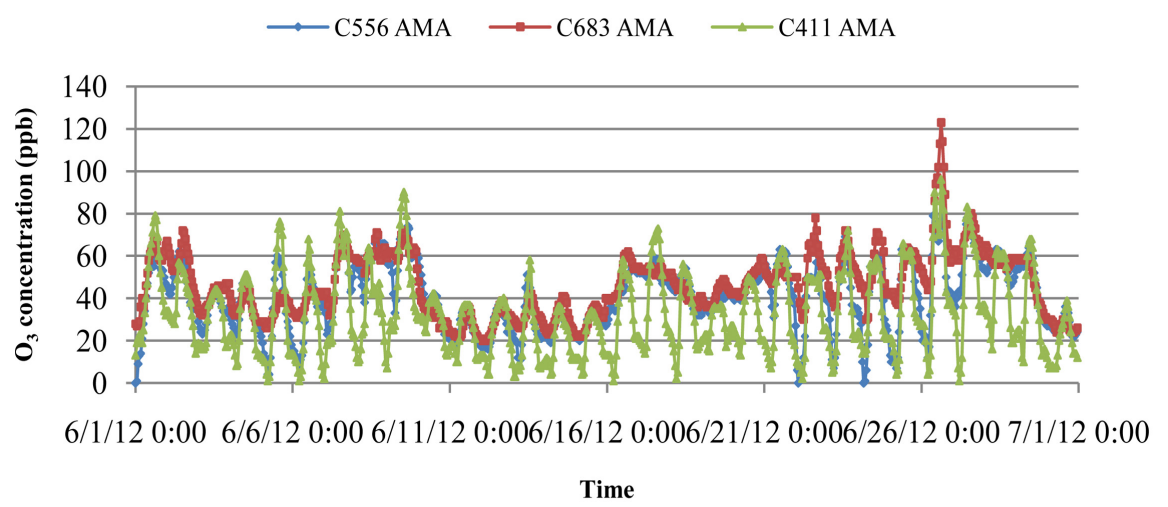

Figure 5. Hourly $\mathrm{O}_{3}$ concentrations at different locations for AMA (All sources-Area sources) case. 
days of the episode, while high concentrations shifted towards Galveston with some variations in the rest of the month. The complex meteorology, such as wind direction, speed, etc., can cause the variation in high ozone levels at different locations in the same region.

The relative contributions to hourly high ( $\geq 75 \mathrm{ppb}$ considered) ozone formation of individual source categories are shown in Figures 6-8. The values of $21.45 \% \pm 7.37 \%, 20.60 \% \pm 6.89 \%$, and $5.21 \% \pm 1.59 \%$ were observed from point sources, mobile sources, and area sources, respectively, at C411 (Table 1). Most of the daily high hours occurred during daytime in the downtown location, and the emission from diesel engines and highway gasoline vehicles have a major influence on the average daytime concentration [43]. A recent study by TCEQ has concluded that mobile sources are responsible for the $\mathrm{NO}_{\mathrm{x}}$ emission from anywhere between from $50 \%$ to $80 \%$ in the urban areas of the state of Texas [44]. At the Houston Ship Channel site, point sources $(27.51 \% \pm 3.53 \%)$ were the highest contributors to ozone formation in the study period followed by the mobile source category $(18.27 \% \pm 2.22 \%)$ and the area sources $(4.19 \% \pm 1.65 \%)$. Similarly, the top contributor was point sources at Site C683 in the Galveston area. The contributions from the point, mobile, and area sources were $30.30 \% \pm$ $9.31 \%, 18.61 \% \pm 7.43 \%$, and $3.72 \% \pm 1.52 \%$, respectively.

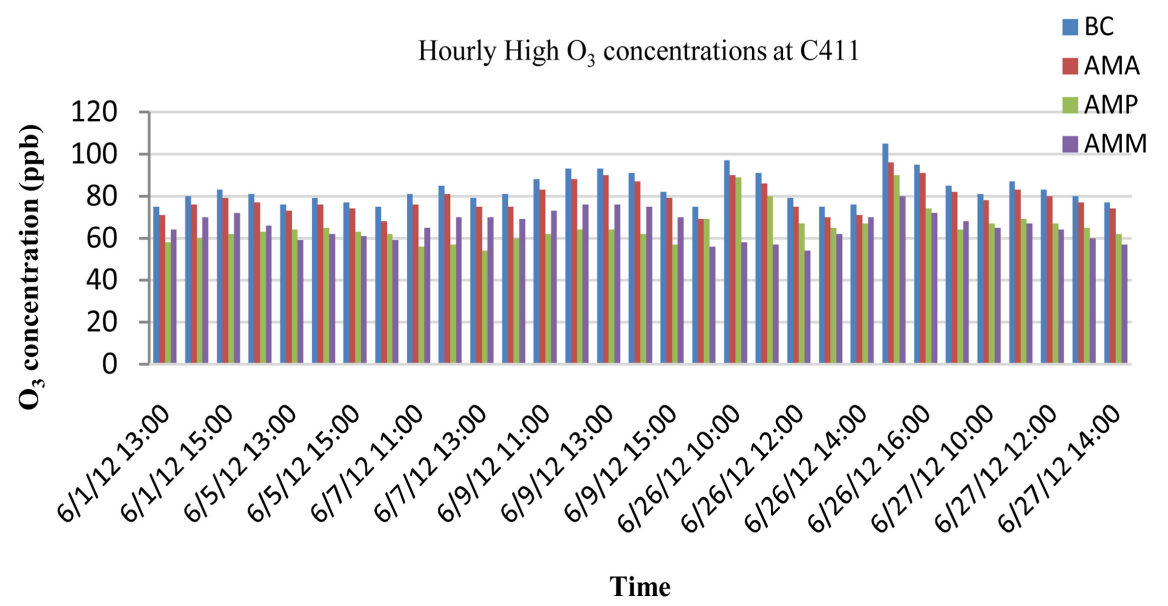

Figure 6. The relative contributions of major sources to the $\mathrm{O}_{3}$ formation at C411.

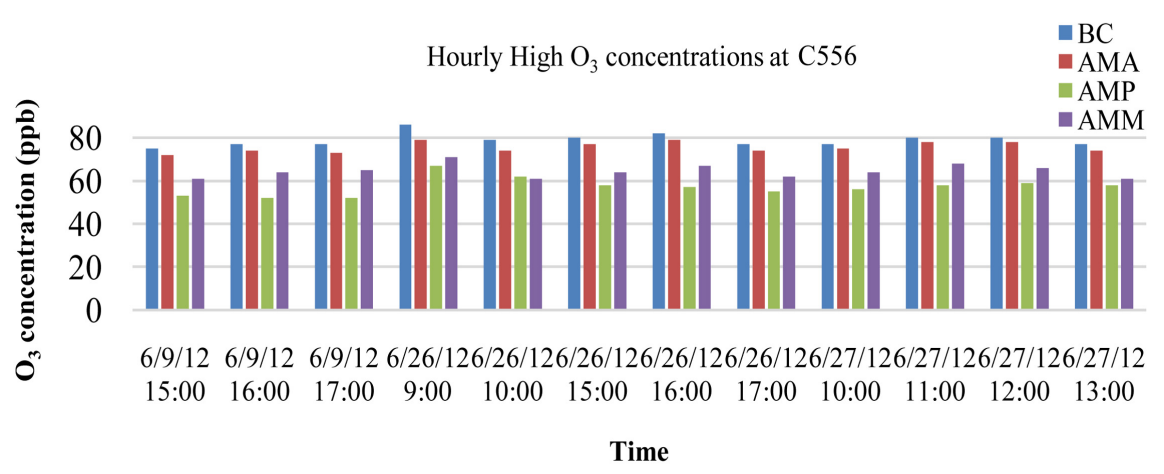

Figure 7. The relative contributions of major sources to the $\mathrm{O}_{3}$ formation at C556. 


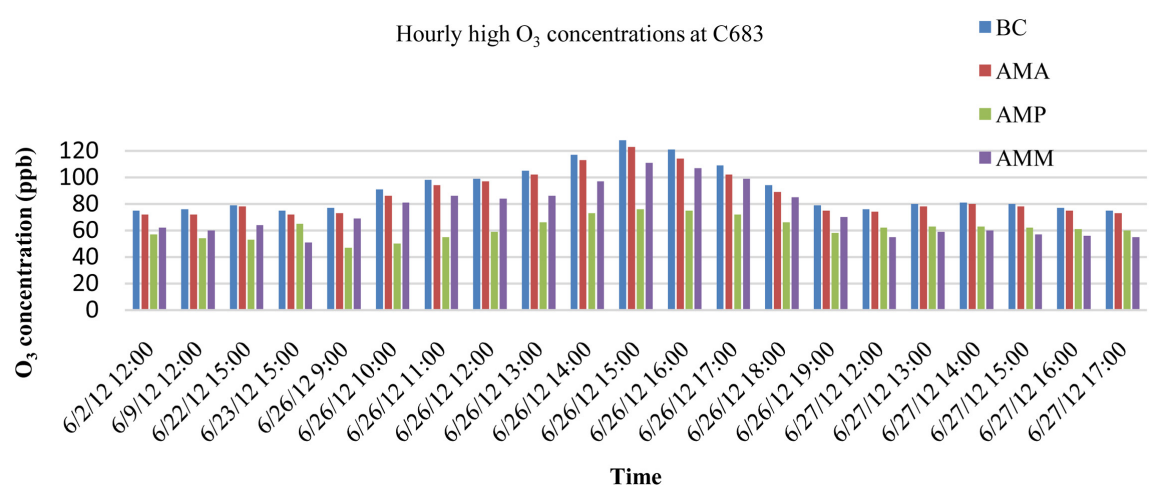

Figure 8. The relative contributions of major sources to the $\mathrm{O}_{3}$ formation at C683.

Table 1. The relative contributions (percentage) of different anthropogenic sources to high $\mathrm{O}_{3}$ concentrations.

\begin{tabular}{cccc}
\hline Site & Point Sources & Mobile Sources & Area Sources \\
\hline Houston Downtown & $21.45 \% \pm 7.37 \%$ & $20.60 \% \pm 6.89 \%$ & $5.21 \% \pm 1.59 \%$ \\
Houston Ship Channel & $27.51 \% \pm 3.53 \%$ & $18.27 \% \pm 2.22 \%$ & $4.19 \% \pm 1.65 \%$ \\
Galveston & $30.30 \% \pm 9.31 \%$ & $18.61 \% \pm 7.43 \%$ & $3.72 \% \pm 1.52 \%$ \\
\hline
\end{tabular}

At all three sites, the point source category dominated ozone formation, and at the Galveston site the scale of contribution is the highest from the same source category. However, at Houston downtown, both the mobile sources and point sources contributed in a similar range. Kommalapati et al. (2018) observed that the biogenic sources contributed an average of $43.1 \% \pm 12.0 \%$ of all sources at Bayland park near Houston downtown to ozone formation and also noted that the contribution is $76.3 \% \pm 7.20 \%$ from biogenic and mobile sources together [18]. According to Qi Ying, the largest anthropogenic sources of ozone formation are industrial sources followed by gasoline vehicles and solvent utilization in the HGB area [45]. The same study also revealed that industrial sources contributed a peak value of $6.6 \mathrm{ppb} \mathrm{hr}^{-1}$ in the ship channel region, and the VOCs from the diesel vehicle contributing to ozone formation in the urban Houston is not significant.

The downtown site C411 is located near Highways I-45 and I-69, which causes the greater influence of mobile sources on this location than both ship channel and Galveston sites. A recent study concluded that mobile sources are responsible for $67 \%$ of $\mathrm{NO}_{\mathrm{x}}$ emissions and $23 \%$ of VOC emissions in the HGB area [44]. Highly reactive VOCs from local point sources greatly influence the ozone formation in Houston [46]. According to a CMAQ model analysis by Xiao et al. (2010), the petrochemical facilities in the HSC region are significant contributors to peak ozone levels in the Houston region [47]. Our study reveals that the ozone exceedances in the study region in the June episode are greatly affected by point sources such as power plants, refineries, chemical manufacturing facilities, etc. followed by mobile sources, which include on-road, off-road, and non-road vehicles. Even though area sources emit large amounts of VOCs, this study 
found that the area source category has much lower influence than the other anthropogenic sources in the HGB area. The background ozone, which is the amount of ozone due to the distant sources, can come from natural processes, such as wildfires, and can be transported from international pollution sources. It also plays a role in ozone exceedance in the HGB area. For example, a study conducted on 2000-2015 ozone exceedances reported that $62 \%$ of exceedances days could be avoided if $30 \%$ of background ozone was reduced [48]. Outcomes from this research suggest that regulatory focus on the point and mobile sources would yield better results on controlling ozone exceedances in the HGB area.

\section{Conclusion}

The mobile and point source emissions caused more elevated ozone hours at Houston downtown-C411 location than the other two sites. The lower diurnal ozone deviations were observed at C683 while higher variation is in the downtown area, and usually, the sharp increase of ozone occurred during the daytime between 10:00-16:00 $\mathrm{hr}$. The relative contributions of point sources at C411, C556, and C683 are $21.45 \% \pm 7.36 \%, 27.51 \% \pm 3.53 \%$, and $30.30 \% \pm 9.36 \%$, respectively, and they were the largest contributors among all the sources in the study region followed by mobile sources. The emission from area sources had much less effect on ozone formation, and the order of contributions was point sources $>$ mobile sources $>$ area sources. The study indicates that policymakers should focus on controlling point and mobile source emissions to meet ozone NAAQS. This study adopted the zero-out method which may not be the most accurate method for the highly non-linear species; however, it does provide a valuable analysis. Methods like OSAT and DDM can be used to incorporate the non-linearity into future studies; along with the analysis to study the impact of different emission source categories on the ozone precursors may provide useful information to regulatory agencies. We would like to suggest that a longer period, the selection of more sites, and updated emission data in recent years could be considered for a more in-depth analysis of ozone sources in the HGB area.

\section{Acknowledgements}

This research is supported by the National Science Foundation (NSF) through the Center for Energy and Environmental Sustainability (CEES) - Phase II, an NSF CREST Center (Award \# 1914692). The authors are responsible for the technical content of this study.

\section{Conflicts of Interest}

The authors declare no conflicts of interest regarding the publication of this paper.

\section{References}

[1] Sillman, S. (1999) The Relation between Ozone, $\mathrm{NO}_{x}$, and Hydrocarbons in Urban 
and Polluted Rural Environments. Atmospheric Environment, 33, 1821-1845. https://doi.org/10.1016/S1352-2310(98)00345-8

[2] Crutzen, P. (1974) Photochemical Reactions Initiated by and Influencing Ozone in Unpolluted Tropospheric Air. Tellus A, 26, 47-57.

https://doi.org/10.3402/tellusa.v26i1-2.9736

[3] Atkinson, R. (2000) Atmospheric Chemistry of VOCs and $\mathrm{NO}_{x}$. Atmospheric Environment, 34, 2063-2101. https://doi.org/10.1016/S1352-2310(99)00460-4

[4] Finlayson-Pitts, B.J. (1997) Tropospheric Air Pollution: Ozone, Airborne Toxics, Polycyclic Aromatic Hydrocarbons, and Particles. Science, 276, 1045-1051. https://doi.org/10.1126/science.276.5315.1045

[5] Simon, H., Reff, A., Wells, B., Xing, J. and Frank, N. (2015) Ozone Trends across the United States over a Period of Decreasing $\mathrm{NO}_{x}$ and VOC Emissions. Environmental Science \& Technology, 49, 186-195. https://doi.org/10.1021/es504514z

[6] EPA (2018) Table of Historical Ozone National Ambient Air Quality Standards (NAAQS).

https://www.epa.gov/ground-level-ozone-pollution/table-historical-ozone-nationalambient-air-quality-standards-naaqs

[7] Kleinman, L.I., Daum, P.H., Imre, D., Lee, Y.N., Nunnermacker, L.J., Springston, S.R., Weinstein-Lloyd, J. and Rudolph, J. (2003) Correction to "Ozone Production Rate and Hydrocarbon Reactivity in 5 Urban Areas: A Cause of High Ozone Concentration in Houston". Geophysical Research Letters, 30, 1639.

https://doi.org/10.1029/2003GL017485

[8] TCEQ (2019) Houston-Galveston-Brazoria: Current Attainment Status. https://www.tceq.texas.gov/airquality/sip/hgb/hgb-status

[9] Lin, C.J., Ho, T.C., Chu, H.W., Yang, H., Chandru, S., Krishnarajanagar, N., Chioue, P. and Hopper, J.R. (2005) Sensitivity Analysis of Ground-Level Ozone Concentration to Emission Changes in Two Urban Regions of Southeast Texas. Journal of Environmental Management, 75, 315-323. https://doi.org/10.1016/j.jenvman.2004.09.012

[10] TCEQ (2020) Ozone: The Facts. https://www.tceq.texas.gov/airquality/monops/ozonefacts.html

[11] Kleinman, L.I., Daum, P.H., Imre, D., Lee, Y.N., Nunnermacker, L.J., Springston, S.R., Weinstein-Lloyd, J. and Rudolph, J. (2002) Ozone Production Rate and Hydrocarbon Reactivity in 5 Urban Areas: A Cause of High Ozone Concentration in Houston. Geophysical Research Letters, 29, 105-110. https://doi.org/10.1029/2001GL014569

[12] Rappenglück, B., Perna, R., Zhong, S. and Morris, G.A. (2008) An Analysis of the Vertical Structure of the Atmosphere and the Upper-Level Meteorology and Their Impact on Surface Ozone Levels in Houston, Texas. Journal of Geophysical Research: Atmospheres, 113, D17315. https://doi.org/10.1029/2007JD009745

[13] Murphy, C.F. and Allen, D.T. (2005) Hydrocarbon Emissions from Industrial Release Events in the Houston-Galveston Area and Their Impact on Ozone Formation. Atmospheric Environment, 39, 3785-3798. https://doi.org/10.1016/j.atmosenv.2005.02.051

[14] Flues, M., Hama, P., Lemes, M.J.L., Dantas, E.S.K. and Fornaro, A. (2002) Evaluation of the Rainwater Acidity of a Rural Region Due to a Coal-Fired Power Plant in Brazil. Atmospheric Environment, 36, 2397-2404. https://doi.org/10.1016/S1352-2310(01)00563-5

[15] Brock, C.A., Trainer, M., Ryerson, T.B., Neuman, J.A., Parrish, D.D., Holloway, J.S., 
Nicks, D.K., Frost, G.J., Hübler, G., Fehsenfeld, F.C., Wilson, J.C., Reeves, J.M., Lafleur, B.G., Hilbert, H., Atlas, E.L., Donnelly, S.G., Schauffler, S.M., Stroud, V.R. and Wiedinmyer, C. (2003) Particle Growth in Urban and Industrial Plumes in Texas. Journal of Geophysical Research: Atmospheres, 108, 4111. https://doi.org/10.1029/2002JD002746

[16] Srivastava, R.K., Miller, C.A., Erickson, C. and Jambhekar, R. (2004) Emissions of Sulfur Trioxide from Coal-Fired Power Plants. Journal of the Air \& Waste Management Association, 54, 750-762. https://doi.org/10.1080/10473289.2004.10470943

[17] Hossan, I., Botlaguduru, V., Du, H., Kommalapati, R. and Huque, Z. (2018) Air Quality Impact of Biomass Co-Firing with Coal at a Power Plant in the Greater Houston Area. Open Journal of Air Pollution, 7, 263-285.

https://doi.org/10.4236/ojap.2018.73013

[18] Kommalapati, R., Shahriar, M., Botlaguduru, V., Du, H. and Huque, Z. (2018) Relative Contribution of Different Source Categories to Ozone Exceedances in the Houston-Galveston-Brazoria Area. Journal of Environmental Protection, 9, 847-858. https://doi.org/10.4236/jep.2018.98052

[19] Reiss, R. (2006) Temporal Trends and Weekend-Weekday Differences for Benzene and 1,3-butadiene in Houston, Texas. Atmospheric Environment, 40, 4711-4724. https://doi.org/10.1016/j.atmosenv.2006.04.023

[20] Nielsen-Gammon, J.W., Tobin, J. and McNeel, A. (2005) A Conceptual Model for Eight-Hour Ozone Exceedances in Houston, Texas. Part II: Eight-Hour Ozone Exceedances in the Houston-Galveston Metropolitan Area. HARC/TERC/TCEQ Report, 79.

https://oaktrust.library.tamu.edu/bitstream/handle/1969.1/158249/houzone3.pdf?se quence $=1$ \&isAllowed $=y$

[21] Banta, R.M., Senff, C.J., et al. (2005) A Bad Air Day in Houston. American Meteorological Society, 86, 657-669. https://doi.org/10.1175/BAMS-86-5-657

[22] Ryerson, T.B., et al. (2003), Effect of Petrochemical Industrial Emissions of Reactive Alkenes and $\mathrm{NO}_{x}$ on Tropospheric Ozone Formation in Houston, Texas. Journal of Geophysical Research, 108, 4249. https://doi.org/10.1029/2002JD003070

[23] Darby, L.S. (2005) Cluster Analysis of Surface Winds in Houston, Texas, and the Impact of Wind Patterns on Ozone. Journal of Applied Meteorology, 44, 1788-1806. https://doi.org/10.1175/JAM2320.1

[24] Nam, J., Kimura, Y., Vizuete, W., Murphy, C. and Allen, D.T. (2006) Modeling the Impacts of Emission Events on Ozone Formation in Houston, Texas. Atmospheric Environment, 40, 5329-5341. https://doi.org/10.1016/j.atmosenv.2006.05.002

[25] Langford, A.O., Senff, C.J., Banta, R.M., et al. (2009) Regional and Local Background Ozone in Houston during Texas Air Quality Study 2006. Journal of Geophysical Research, 114, D00F12. https://doi.org/10.1029/2008JD011687

[26] Zhang, H., Li, J., Ying, Q., Yu, J.Z., Wu, D., Cheng, Y., He, K. and Jiang, J. (2012) Source Apportionment of PM2.5 Nitrate and Sulfate in China Using a Source-Oriented Chemical Transport Model. Atmospheric Environment, 62, 228-242. https://doi.org/10.1016/j.atmosenv.2012.08.014

[27] Wang, X., Li, J., Zhang, Y., et al. (2009) Ozone Source Attribution during a Severe Photochemical Smog Episode in Beijing, China. Science in China Series B: Chemistry, 52, 1270-1280. https://doi.org/10.1007/s11426-009-0137-5

[28] Li, K., Lau, A., Fung, J.C.-H., Zheng, J.Y., Zhong, L.J. and Louie, P.K.K. (2012) Ozone Source Apportionment (OSAT) to Differentiate Local Regional and Super-Regional Source Contributions in the Pearl River Delta Region, China. Journal 
of Geophysical Research, 117, D15305. https://doi.org/10.1029/2011JD017340

[29] EPA (2010) Peer Review of Source Apportionment Tools. https://www.epa.gov/sites/production/files/2020-10/documents/sourceapportionme ntpeerreview.pdf

[30] Farooqui, Z.M., et al. (2013) Modeling Analysis of the Impact of Anthropogenic Emission Sources on Ozone Concentration over Selected Urban Areas in Texas. Atmospheric Pollution Research, 4, 33-42. https://doi.org/10.5094/APR.2013.004

[31] Collet, S., et al. (2018) Future Year Ozone Source Attribution Modeling Study Using CMAQ-ISAM. Journal of Air and Waste Management Association, 68, 1239-1247. https://doi.org/10.1080/10962247.2018.1496954

[32] TCEQ (2020) Texas Air Quality Modeling-Files and Information (2012 Episodes). https://www.tceq.texas.gov/airquality/airmod/data/tx2012

[33] ENVIRON (2016) CAMx Source Code and Documentation. http://camx-wp.azurewebsites.net/Files/CAMxUsersGuide_v6.30.pdf

[34] EPA (2018) Final Area Designation for the 2015 Ozone National Ambient Air Quality Standards Technical Support Document. https://www.epa.gov/sites/production/files/2018-05/documents/tx_tsd_final.pdf

[35] EPA (2018) Approval and Promulgation of Implementation Plans; Texas; Attainment Demonstration for the Houston-Galveston-Brazoria Ozone Nonattainment Area. 83FR 24446; EPA-R06-OAR-2017-0053-FRL-9978-46-Region 6.

[36] TCEQ (2015) Redesignation Substitute Report for the Houston-Galveston-Brazoria 1997 Eight-Hour-Ozone Standard Nonattainment Area.

https://www.tceq.texas.gov/assets/public/implementation/air/sip/hgb/1997ozone_R S_Report/HGB_RS_1997_8Hr_report.pdf

[37] Liu, L., et al. (2015) Influence of Climate Change and Meteorological Factors on Houston's Air Pollution: Ozone a Case Study. Atmosphere, 6, 623-640.

https://doi.org/10.3390/atmos6050623

[38] TCEQ (2020) Texas Air Quality Modeling-Files and Information. https://www.tceq.texas.gov/airquality/airmod/data/tx/2012

[39] TCEQ (2009) Houston-Galveston-Brazoria Nonattainment Area Ozone Conceptual Model.

https://www.tceq.texas.gov/assets/public/implementation/air/am/modeling/hgb8h2/ doc/HGB8H2_Conceptual_Model_20090519.pdf

[40] TCEQ (2017) Information Submitted for the Limestone Generating Station and the WA Parish Electric Generating Station (Attachment F).

https://www.tceq.texas.gov/assets/public/implementation/air/sip/so2/2015RevisedR ecommendation/Att_F_NRG.pdf

[41] Daum, P.H., Kleinman, L.I., Springston, S.R., Nunnermacker, L.J., Lee, Y., Weinstein-Lloyd, J., Zheng, J. and Berkowitz, C.M. (2003) A Comparative Study of O3 Formation in the Houston Urban and Industrial Plumes during the 2000 Texas Air Quality Study. Journal of Geophysical Research, 108, 18 p. https://doi.org/10.1029/2003JD003552

[42] Jiang, G. and Fast, J.D. (2004) Modeling the Effects of VOC and NOX Emission Sources on Ozone Formation in Houston during the TexAQS 2000 Field Campaign. Atmospheric Environment, 38, 5071-5085.

https://doi.org/10.1016/j.atmosenv.2004.06.012

[43] Zhang, H. and Ying, Q. (2011) Contributions of Local and Regional Sources of $\mathrm{NO}_{x}$ to Ozone Concentrations in Southeast Texas. Atmospheric Environment, 45, 2877- 
2887. https://doi.org/10.1016/j.atmosenv.2011.02.047

[44] TCEQ (2019) Texas Emission Sources-A Graphical Representation. https://www.tceq.texas.gov/airquality/areasource/emissions-sources-charts

[45] Ying, Q. (2009) Source Contributions of Volatile Organic Compounds to Ozone Formation in Southeast Texas. The 8th Annual CMAS Conference, Chapel Hill, 19-21 October 2009, 1-6.

https://www.cmascenter.org/conference/2009/abstracts/ying_source_contributions_ 2009.pdf

[46] Kemball-Cook, S., Parish, D., et al. (2009) Contributions of Regional Transport and Local Sources to Ozone Exceedances in Houston and Dallas: Comparison of Results from a Photochemical Grid Model to Aircraft and Surface Measurements. Journal of Geophysical Research, 114, D00F02. https://doi.org/10.1029/2008JD010248

[47] Xiao, X., Cohan, D.S., Byun, D.W. and Ngan, F. (2010) Highly Nonlinear Ozone Formation in the Houston Region and Implications for Emission Controls. Journal of Geophysical Research, 115, D23309. https://doi.org/10.1029/2010JD014435

[48] Wang, Y.X. and Talbot, R. (2017) High Background Ozone Events in the Houston-Galveston-Brazoria Area: Causes, Effects, and Case Studies of Central American Fires. Texas Air Quality Research Program. AQRP Project 16-008.

http://aqrp.ceer.utexas.edu/projectinfoFY16_17/16-008/16-008\%20Final\%20Report. pdf 


\section{Appendix A}

Figure A1 Shows the time series data for the modeled and observed ozone in June 2012 at the study sites.
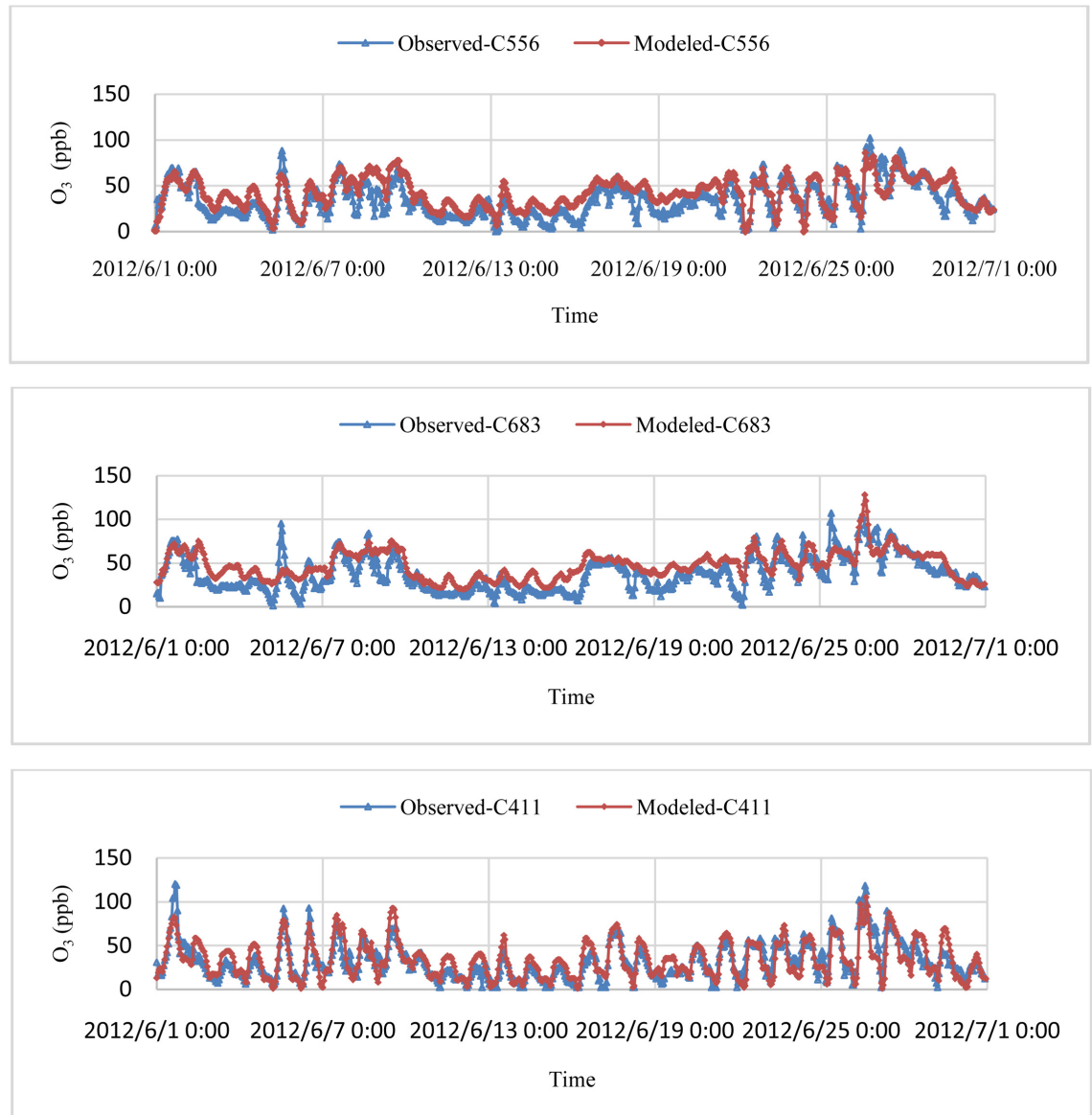

Figure A1. Modeled vs Observed data for the sites C556, C683, C411. 